\title{
\begin{tabular}{|l|l|} 
University of & FOUNDED \\
St Andrews & 1413
\end{tabular}
}

University

Library

\section{Sherlock Holmes and risk}

James Purdon

\begin{tabular}{|l|l|}
\hline Date of deposit & $08 / 08 / 2018$ \\
\hline Document version & Author's accepted manuscript \\
\hline Access rights & $\begin{array}{l}\text { C } 2018 \text { John Wiley \& Sons Ltd. This work is made available online } \\
\text { in accordance with the publisher's policies. This is the author } \\
\text { created, accepted version manuscript following peer review and } \\
\text { may differ slightly from the final published version. }\end{array}$ \\
\hline $\begin{array}{l}\text { Citation for } \\
\text { published version }\end{array}$ & $\begin{array}{l}\text { Purdon, J. (2018). Sherlock Holmes and risk. Critical Quarterly, } \\
60(3), 14-28 .\end{array}$ \\
\hline $\begin{array}{l}\text { Link to published } \\
\text { version }\end{array}$ & https://doi.org/10.1111/criq.12423 \\
\hline
\end{tabular}

Full metadata for this item is available in St Andrews Research

Repository at: https://research-repository.st-andrews.ac.uk/

\section{St Andrews Research Repository}




\section{Sherlock Holmes and Risk}

There is always a risk, my dear captain. There is nothing in the world without risk.

Arthur Conan Doyle, The Firm of Girdlestone'

In "Studies in the Literature of Sherlock Holmes", presented to the University of Oxford's Gryphon Club in 1911, the young don Ronald Knox - later Monsignor Knox, priest and detective novelist - set out to explain away some of the notorious inconsistencies and implausibilities that dog the most famous stories of Arthur Conan Doyle. The difficulties were as stark as those in any case investigated by Holmes himself. How can the consulting detective speak, in "The Adventure of the Musgrave Ritual", of his "last years" at University, when we know from "The Adventure of the Gloria Scott" that he spent only two years there? How, in "The Adventure of the Three Students", can a pencil bearing the maker's name of "Johann Faber" be sharpened down so that only the letters "NN" appear on the stub? And how, in "The Adventure of the Solitary Cyclist", can a forced marriage take place in the absence of any witness?

The paper, an academic jeu d'esprit that has inspired more than a century of "Sherlockian" psuedocriticism, is a fine specimen of the kind of diversion that served to keep literary youths off the streets of Oxford in the early years of the last century. Tongue squarely in the cheek of a studiously straight face, Knox takes the Holmes stories at their word as real memoirs ("a reprint from the reminiscences of JOHN H. WATSON, M.D., late of the Army Medical Department”, as Doyle inscribes the first of them) and makes it his business to explain away 
those notorious inconsistencies by way of demonstrating his own critical ingenuity. Insisting on the reality of the Holmes stories, Knox suggests that any implausibilities in their telling must be down to errors in transmission introduced by Holmes's chronicler; his ingenious solution is to posit the authorial intervention of a later Doctor Watson, fallen on hard times and now producing false Holmes chronicles for the market without due attention to detail.

What distinguishes Knox from so many of his Sherlockian followers, who have on the whole managed to emulate his faux-scholarly seriousness without the critical sharpness or leavening wit, is the sense of irony that he shares with the author of the stories. Like Doyle, he seems able to take the adventures of Holmes and Watson both more seriously and less seriously than they deserve. On at least one occasion, however, Knox's enthusiasm for the subject leads him to an assessment of Holmes's methods that is not fully borne out by the stories themselves. The question turns on the contribution of luck to Holmes's successes. Comparing Holmes to Gaboriau's Monsieur Lecoq, Knox finds the French detective lacking in the capacity for intense ratiocination that Holmes has developed into a fine art, and therefore more dependent on the intervention of chance:

Lecoq [...] has not the method of deduction - he never sits down and reasons out what is probable the man would have done next. Lecoq has his lens and his forceps: he has not the dressing-gown and the pipe. That is why he has to depend on mere chance, again and again, for picking up lost threads. Holmes no more depended on a chance than he prayed for a miracle. ${ }^{2}$

Insisting on Holmes's methodical nature, Knox here follows Watson's assessment of his friend as "an automaton, - a calculating machine" who owes his success to his "quiet and systematic method of work", as well as Holmes's own account of the "habits of observation and inference" which he has "formed into a system" (pp. 96, 343, 375). ${ }^{3}$ Yet Knox is not quite right to suggest that Holmes never depends on chance. "[I]n any case," the detective tells Watson in "The Adventure of the Blue Carbuncle", "we have a line of investigation which has been missed by 
the police, and which a singular chance has placed in our hands" (p. 252). According to Holmes himself, the solution to "The Adventure of the Golden Pince-Nez" rests upon the "fortunate chance" of the dying Willoughby Smith having caught hold of the murderer's eyewear (p. 621). And he readily admits, in The Valley of Fear, that he has come to possess intimate knowledge of Professor Moriarty’s finances “quite by chance” (p. 777).

The importance of chance to the Holmes stories has occasionally been noted only to be dismissed as a symptom of authorial absent-mindedness. Christopher Clausen, for instance, points out that although Holmes "frequently denounces guesswork, at times he seems alarmingly dependent on lucky intuitions”. ' Clausen reads Doyle’s stories as a conservative wish-fulfilment fantasy in which an exceptional and eccentric gentleman-amateur turns his extraordinary capacity for ratiocination to the task of expunging those chaotic, unruly, and irrational elements which threaten the peaceful, civilized order of the English social system. Yet this account of Holmes as an embodiment of modern reason and method depends upon just the same kind of hygienic process, one in which the troubling contribution of "lucky intuitions" to Holmes's achievements is no sooner acknowledged than suppressed. If Holmes purifies England, Clausen purifies Holmes. "It would be possible to pick many holes in both his methods and his conclusions," he continues; nevertheless, the "important point" is that Holmes "is conceived - and conceives of himself - as a man who applies scientific methods to the detection of crime, and [...] his success as a detective is due to those methods.”

That has certainly seemed the important point to most of Holmes's admirers, from Doctor Watson and Ronald Knox to Clausen himself. I am not so sure. Knox may be right insofar as Holmes is never content to leave his investigations entirely to the workings of chance, but his method of reasoning and his store of knowledge frequently succeed precisely because they put him in a position to act on chance occurrences before anyone else recognises their significance. 
In what follows, I propose to keep an eye on the lucky chances that pervade Doyle's stories by way of suggesting that what they teach readers to value is not so much the logical application of scientific method as the ability to master chance by assessing and incorporating tolerable levels of risk into the workings of an orderly system. That was an ability uniquely prized in the newly risk-positive climate of late-Victorian and Edwardian England.

Mr. Sherlock Holmes seems something of a risky proposition himself when, in A Study in Scarlet (1887), he and Watson are introduced by their mutual acquaintance Stamford, whom Watson chances upon at the bar of the Criterion. Before they meet for the first time, Watson has already learned from Stamford that his prospective house-mate spends his leisure hours attempting to raise bruises on the cadavers in the dissecting-room, and is thought to be the sort of fellow who might dose a friend with "a little pinch of the latest vegetable alkaloid [...] simply out of a spirit of inquiry" (p. 17). Fortunately for Watson, Stamford is only half right: when Holmes later obtains a sample of the alkaloid poison used by the murderer Jefferson Hope, he tests it not on his new associate but on his landlady's ailing terrier.

Even so, Holmes is evidently the kind of unpredictable personality whose behaviour might give rise to a gentlemanly bet: "You must study him", Stamford tells Watson. "You'll find him a knotty problem, though. I'll wager he learns more about you than you about him” (p. 19). Watson seems to pick up the hint in Stamford's sporting turn of phrase when, sitting down to breakfast not long after having moved with Holmes into rooms in Baker Street, he happens upon a magazine article ("The Book of Life") whose author claims to be able to assess at a glance the occupation and antecedents of a stranger from the minutest evidence of physiognomy and dress. Watson is skeptical. "I should like to see him clapped down in a third class carriage on the Underground, and asked to give the trades of all his fellow-travellers. I would lay a thousand to one against him." Holmes's dry response: "You would lose your 
money. [...] As for the article I wrote it myself” (p. 23). Our earliest introduction to Holmes as readers, then, is as an object of other people's wagers - but it is not long before he begins laying bets of his own. Summoned to consult on the murder of an unknown American gentleman at an address in Lauriston Gardens, he quickly determines that the murderer returned, disguised as a loitering drunk, in order to recover a woman's wedding-ring left at the scene of the crime. "I shall have him, Doctor-", he exclaims to Watson, "I'll lay you two to one that I have him" (p. 36).

Such offhand talk about bets and wagers is a constant throughout the Holmes canon, where sporting gentlemen rub shoulders with unscrupulous card-sharps and unwise speculators. It goes unnoticed as part of the idiom proper to the period and the milieu. But the density of gambling language at the beginning of $A$ Study in Scarlet, when Holmes and his world are being established for the first time, points insistently to the themes of chance and risk that pervade this novel in particular. It is chance that presents Jefferson Hope with the key to the empty house in Lauriston Gardens where he commits the murder, after a passenger leaves it in his cab, and "the merest chance" that prompts Inspector Lestrade to retain the crucial clue: a box of poisoned pills from the second crime scene at Halliday's Private Hotel (p. 48). Most significantly, the Lauriston Gardens murder itself turns out to be not only the result of a gamble - since it transpires that Jefferson Hope, seeking vengeance for the death of his fiancée, has compelled his victim to choose between a poison pill and a placebo - but a defiant affirmation of a world in which chance must be subordinated to providence, as its perpetrator explains:

\footnotetext{
"But it was you who broke her innocent heart," I shrieked, thrusting the box before him. "Let the high God judge between us. Choose and eat. There is death in one and life in the other. I shall take what you leave. Let us see if there is justice upon the earth, or if we are ruled by chance.” (p. 81)
}

Hope's words are later echoed by Holmes himself in a moment of uncharacteristically metaphysical contemplation in "The Adventure of the Cardboard Box" (1893): "What object is 
served by this circle of misery and violence and fear? It must tend to some end, or else our universe is ruled by chance, which is unthinkable” (p. 901). Neither Hope nor Holmes wants to believe in a universe ruled by chance, even if chance plays a decisive role both in Hope's crime and in Holmes's investigation. Each therefore congratulates himself not on his good luck exactly, but on his ability to recognise and take advantage of the chances that luck has placed in his path. Hope takes a copy of the lost key, while Holmes recognises the link between the poisoned man and the box of pills. "All this seems strange to you," he tells Lestrade, "because you failed at the beginning of the inquiry to grasp the importance of the single real clue which was presented to you. I had the good fortune to seize upon that” (p. 49). But both murderer and detective are willing to leave only so much to chance. Jefferson Hope stabs his second victim, who refuses to choose between the pills; Holmes already knows the name of the murderer before confirming his theory about the poison.

Chance had come to constitute a particularly difficult moral problem in Victorian Britain, where - as Hope's and Holmes's words imply - it was no longer generally conceived as the handmaiden of divine providence, but rather as one possible alternative to it. The discovery, during the latter half of the century, of statistical laws which rendered seemingly random events predictable given large enough sets of data, helped to demystify the idea of chance, making it a moral rather than a metaphysical problem. The effects of this new attitude to chance were to be seen most clearly in mid-century legislative and discursive attempts to control the problem of gambling.

Outright gambling (with the exception of on-course betting at horse-races) had been banned in Britain, somewhat ineffectually, by the Gaming Act 1845 and the Betting Act 1853. Gentlemen were still free to bet at their clubs, and the lower classes had recourse to bookmakers operating from private premises or on street-corners, but betting contracts were made unenforceable in 
the law-courts and the keeping of gaming-houses was prohibited. The legislation also had a second purpose: to draw a line between the morally dubious pastime of common gambling and the economically desirable (though not altogether dissimilar) practices of stock-market speculators whose capital remained essential to the growth of Britain's commercial activity at home and across the Empire. By outlawing the riskiest and most controversial types of speculative wagering on the stock exchange, the government hoped to prevent the kind of share price inflation which had led to the disastrous South Sea Bubble of 1720 and fuelled the "Railway Mania" of the mid-1840s.

One of the major objections to gambling was, as Roger Munting has noted, that "[t]he reliance on chance to determine income and fortune flew in the face of the work ethic and the spirit of capitalism". If capitalism was to be accepted as not only economically but morally legitimate, profits had to be in some sense deserved. But the wildly unpredictable wins and losses of stock speculators, and the cycle of boom-and-bust economic crises that periodically wracked the national (and by the end of the century, the global) economy, struck many Victorian observers as being more readily attributable to luck than desert. "Speculation is a round game", writes Dickens in the first chapter of Nicholas Nickleby (1838-9); "the players see little or nothing of their cards at first starting; gains may be great - and so may losses. ${ }^{\circ}$ Both gambling and speculation depended to varying degrees on the operation of chance: the chance that one might be dealt a losing hand, or that the value of a stock might go down rather than up. The willingness of the gambler or speculator to assume the risk associated with that chance was, in theory, what entitled them to their winnings or profits. By the end of the century, the distinction between gambling and speculation was proving even more difficult to maintain than in Dickens's time, as new forms of speculative activity - derivatives, highly-leveraged futures contracts, the conflation of gambling and financial speculation in the trade press of both the 
City and the turf - further eroded the distinction between the respectable speculator and the disreputable gambler.?

Aside from taking a professional interest in commercial crime, Holmes appears to be entirely uninterested - and uninvested - in financial matters. In "The Adventure of the Priory School" we learn that he banks with the Oxford Street branch of the Capital and Counties Bank, but there is no mention in any of the stories of Holmes holding or making any investments, unless one counts his secretly staking the distant relative who buys out Watson's medical practice in "The Adventure of the Norwood Builder". Nor, unlike Watson, does Holmes ever appear to gamble, though he does make a feint of it in "The Adventure of the Blue Carbuncle", where he coaxes information from a tight-lipped poultry-salesman by betting a sovereign he is content to lose.

This financial disinterestedness, like Holmes's aloofness, his drug use, his ignorance of heliocentrism, and so much else, marks him out as an oddity in the fin-de-siècle milieu of the stories, in which one never has to look very far for a ruined gambler or a failed speculator. A bad streak at the card table or the racetrack lies behind more than one of the transgressions investigated by Holmes and Watson. Antagonists like Sir George Burnwell in "The Adventure of The Beryl Coronet" and Count Negretto Sylvius in "The Adventure of The Mazarin Stone" compound their inherent villainy through intemperate gambling, while in the former story the gambling debts of Arthur Holder, the son of the financier to whom the coronet has been entrusted, serve both as an effective red herring and as the occasion for Arthur's redemption when his attempt to recover the treasure is revealed by Holmes. But a downturn on the stock market or the securities exchange plays a similar role in just as many cases. In "The Adventure of the Naval Treaty", for instance, Joseph Harrison pilfers the important document in hope of making good his losses from "dabbling with stocks"; Jonas Oldacre, in "The Adventure of the 
Norwood Builder", is driven to crime by his failures in "secret speculation"; Baron Gruner of "The Adventure of the Illustrious Client" has grown rich "in some rather shady speculations"; and "a Stock Exchange debt" is the motive for Colonel Valentine Walter's theft of state secrets in "The Adventure of the Bruce-Partington Plans" (pp. 467, 510, 987, 930). In "The Adventure of Black Peter", a west-country bank collapse, prompted by unwise investment in poorly-performing securities, proves to be the unlikely beginning of a chain of events that ends with the murder of a retired whaling captain in rural Sussex.

Doyle was not, at least in this matter, inclined to moralise: he presents neither gambling nor speculation as an evil in and of itself. For every Valentine Walter whose unwise investments lead to desperate acts there is a Sir Charles Baskerville, whose well-judged success in "South African speculation" allows him to restore the fortunes of his ancient family and his home county (p. 676). Likewise, for every imprudent Arthur Holder or villainous Sir George Burnwell there is a sensible chap like Watson - who in "The Adventure of Shoscombe Old Place” claims, somewhat unexpectedly, to spend about half his army pension at the racetrack or like Ronald Adair in "The Adventure of the Empty House", who plays cards "continually, but never for such stakes as would hurt him” (pp. 1202, 484). What does hurt him is a bullet fired by Professor Moriarty's henchman, Colonel Sebastian Moran, a less scrupulous gambler who lives "by his ill-gotten card gains", and whom Adair has caught cheating (p. 491). It is in a way fitting that Adair's murder should present the occasion for Holmes's resurrection after his risky gambit at Reichenbach, since the detective himself is inclined to play the odds only when he knows he can afford to do so. His apprehension of Moran strikes a blow for the sporting yet temperate risk-takers of the world against those who would seek to manipulate the moral economy of risk by stacking the odds in their own favour. What is despicable about Moran is not his gambling, but his contravention of the rule that risk and reward should be commensurate. When Holmes tricks him into firing at a wax dummy placed at the window of 
221B, he therefore returns like for like. Moran has reaped rewards at the card table without exposing himself to risk; now, thinking the odds in his favour, he risks too much. Holmes has evened the odds and, in doing so, righted the balance.

An enthusiastic investor, though not always a very prudent one, Doyle was drawn to risky ventures. He had an account with the stockbrokers Pim, Vaughan from the early 1890s, and was able to see the speculative possibilities of his writing as well. When Ward, Lock, \& Co. offered a one-off payment of $£ 25$ for $A$ Study in Scarlet, he wrote back proposing that the publisher pay him royalties instead. ${ }^{8}$ They turned him down, but the request gives a hint of Doyle's willingness to take a financial gamble on his own literary talent, as well as his awareness of his own writing as the kind of commodity on which he could speculate in the hope of future dividends rather than accepting a lump sum.

But Doyle was sufficiently conscious of financial propriety to know when to play down the chances he took. In a letter of 1900 he wrote to his mother offering a reassuring account of his affairs. As the war with the Boers raged on - Doyle himself had just returned from a brief tour as an army doctor and battlefield tourist - Mary Doyle had evidently expressed concern about her son's investments in South Africa. He insisted that his position was secure:

\footnotetext{
What is this about my losses? I was so surprised. No, I have been most fortunate. My heaviest loss was in the most conservative speculation I ever went into, the largest coffee estate in the world, advised by experts to do it. I wish to goodness I had kept that money in what you would call speculative stocks. I don't call well-proved \& old established mining or land shares in South Africa Speculative. [...] I call it gambling when you take up stock \& don’t pay for it. It is legitimate speculation \& using of your wits when you choose your stock \& buy it right out, prepared either to retain it as an investment or to sell it at a large advance.
} 
His "larger investments", he explained, were in property: Undershaw (his home in Surrey) and South View Lodge in Southsea, which he had bought to ease the finances of an old friend. Besides loans to family and the contentious South African shares, he had stakes in Raphael Tuck \& Sons printers, McClure’s magazine, Besson’s musical instrument-makers, Dumont's coffee company, and George Newnes's publishing house - all solid enough prospects - as well as some land in Bournemouth. Doyle was by no means in straitened circumstances, but he was careful about what he divulged to his anxious mother. He may also have been less bullish than he admitted: at the beginning of "The Adventure of the Dancing Men", which appeared in the Strand in December 1903, Doctor Watson steers clear of the South African mining securities offered to him by his billiard-partner Thurston, while the villain of "The Adventure of the Solitary Cyclist" (printed the same month in Collier's) is said to be "deeply interested in South African gold shares” (p. 530).

By the time Doyle published his memoirs in 1924, there could be no cause for concern about his finances, nor was there any need to reassure Mary Doyle, who had died four years earlier. The financial autobiography he offers in Memories and Adventures is more candid, more selfdeprecating, and therefore more entertaining. Here Doyle is at liberty to recount his failures rather than his successes. His occasional investments in guano prospecting and the raising of wrecked Spanish galleons had, he cheerfully admitted, come to naught. He had lost money in Australian gold-mines, in a bicycle factory, in a machine for producing architectural sculptures, and in an ill-fated initiative to mine coal in Kent. Yet he had still managed to turn a profit, and could afford to regard his losses as a necessary cost of doing business:

\footnotetext{
Some of the excitements of my life during these and the subsequent years were due to financial entanglements which arose from a certain speculative element in my own nature, depending rather upon the love of adventure than upon any hope of gain. If when I earned money I had dug a hole in the
} 
garden and buried it there I should be a much richer man to-day. I can hardly blame the punter on the racecourse when I remember the outside chances which I have taken in the past in every possible form of speculation. [...] It is true that sometimes I have indulged in a pure gamble but never for any sum which would hurt me. [...] My speculative adventures are over, and I can at least say that unless the British Empire goes down I shall be able to retain enough for our modest needs. ${ }^{10}$

The Doyle of the memoirs is readier than the Doyle of the private letter to admit the attraction of "outside chances" and the "pure gamble" as well as "legitimate speculation", though there is a hint - "my speculative adventures are over" - that such financial risk-taking represents the kind of youthful indulgence that elderly literary gentlemen might be expected to have outgrown. Forswearing speculation, the older Doyle ties his financial security to an apparently much more stable and certain prospect: the Empire.

In 1900, Doyle had had to reassure his mother that his imperial investments were sound; by 1924, when the British Empire had reached the post-war peak of its territorial expansion, it seemed a more reliable guarantor. Nonetheless, as Doyle's dabblings in South African land and Australian gold-mines suggest, that Empire which now seemed so unassailably secure was itself founded upon a long history of risky speculation. Elaine Freedgood has proposed that, over the course of the nineteenth-century, risk came to be widely understood as part of a complex geographically-structured "cosmology". "Beginning in the 1830s," she argues, "a diverse group of writers labored to help the first victims and beneficiaries of industrialization imagine that danger could be banished from the domestic scene and relocated in the world outside British borders.” Victorian writers consoled themselves by thinking about risk in these spatial terms as a place one could choose to enter or avoid - rather than in terms of an unpredictable and dangerous future. "Careful representations of the precise locations of safety and danger - in such diverse texts as statistical analyses of the British Empire, handbooks of hospital reform, memoirs of balloon aeronauts, travelogues of Alpine mountaineers, and ethnographic studies 
of Africa - suggested that risk could either be avoided altogether (in England) or engaged voluntarily in the dangerous world beyond it". "1

This spatialization of risk is amply illustrated in the outward-bound plots of any number of late Victorian and early Edwardian adventure narratives, from Stevenson's Treasure Island (1882) to Childers's The Riddle of the Sands (1903). It was also intimately connected, as Francis O'Gorman has shown, to the increasing economic importance of risky speculation during the later years of Victoria's reign. Taking the stories of Henry Rider Haggard as his exemplary instances, O’Gorman demonstrates how adventure narratives prioritise the pleasures of risktaking in order to subvert Victorian fiction's ingrained suspicion of the always-dubious speculator or gambler, replacing the speculator-as-villain with a new and admirable kind of economic risk-taker: the imperial "adventurer" ${ }^{12}$

Of the fifty-seven short stories Doyle published about Holmes and Watson, the titles of all but ten explicitly announce their genre as "adventure", a term which in its earliest senses meant a risk or an accident, but which readers had come by the early 1880 s to associate with a distinct, and distinctly modern, kind of narrative. The adventure story was more materialist than gothic fiction, more sensational than the realist novel, and more heartily masculine than the romance. Its main feature was its thrilling presentation of a risky world, governed by the laws of chance, where the odds can nonetheless be counted upon to fall in the hero's favour. At the end of the story, he will emerge from his adventure a wiser, wealthier figure, redeemed by his capacity to face risk, while the laws of chance will in turn have been redeemed by the demonstration of their alliance with the side of right.

The myriad risks to life and limb overcome by Haggard's imperial protagonists, O'Gorman argues, offered late-Victorian readers an acceptable and pleasurable taste of the kind of morally 
ambiguous thrill available to gamblers and financial speculators at home. To invest one's time and attention in the exploits of colonial adventurers was one way of investing imaginatively in a risky global enterprise without the accompanying danger of material loss, and the entwining of personal risk and financial reward bespeaks a new enthusiasm for risk-taking as a moral as well as an economic good. For O'Gorman, the “unspoken and censored truth” that Haggard's stories cannot help disclosing is that the pleasures and rewards offered by risk, whether at the gaming table, on the stock market, or in the African veld, are inextricable from the economic life of late-Victorian capitalism. ${ }^{13}$

Replete with ruined gamblers, shady speculators, and colonial adventurers, Doyle's stories like Haggard's worry obsessively about the operation of chance and the legitimacy of risk, while offering many of the same pleasures. Yet Doyle's attitude to the spatialization of risk underwent some changes in the course of his (and Holmes's) career. By the end of the nineteenth century, the imaginative project of geographically containing risk had begun to crumble under the sustained assault of economic reality. No investor or stock speculator of the 1890s could afford to think about risk in crudely spatial Haggardian terms when their holdings in British companies might be rendered worthless overnight by unforeseen events on the other side of the globe. Bank failures prompted by unwise speculation in foreign markets were a familiar feature of financial and literary life in the years around the fin-de-siècle, and writers were not immune. Rudyard Kipling's savings were all but wiped out in the failure of the New Oriental Banking Corporation in 1892, while Joseph Conrad - never a savvy investor - was caught out by the failure of his bank in 1904 (a Sherlockian critic could make much of the firm's name: Watson \& Co). Many more investors, and their banks, went under as a result of the Panic of 1873 (caused by a complex combination of international events ranging from speculation in American railway bonds to the opening of the Suez Canal) and the Baring crisis of 1890 (a direct result of the venerable merchant bank's risky investment in Argentinian sovereign debt), 
but those were only the two most striking manifestations of the heightened economic risk entailed by the growing interdependency of global financial markets whose operation few individuals were equipped to understand. Financial risk-taking, once the province of gamblers and speculators on the one hand, and colonial adventurers on the other, was integrated into the fundamental structure of modern economic life.

In Doyle's most overtly financial novel, The Firm of Girdlestone (begun in 1884 but not published until the end of the decade and later suppressed by Doyle as a failure), the division is just as stark. Its villains, father-and-son directors of a failing African trading company, plan to make good their disastrous speculative losses by illicitly cornering the world market in diamonds. Their "cunningly devised speculation" involves the fabrication of information about a supposed diamond find in Russia, but fails "due to an accident which could neither have been foreseen nor remedied": a large diamond claim is discovered in the Orange Free State and the bottom falls out of the market. ${ }^{14}$ By the end of the novel, the speculators have fled England; one ends up drowned off the Spanish coast while the other disappears into a life of gambling in America - a fitting end for a speculator. A saccharine final chapter not only marries off the virtuous young protagonists whose lives and reputations have been endangered by the Girdlestones' scheme, but miraculously revives the fortunes of the company by way of providing for them. The wedding takes place in a shabby English church, far from the speculative risks of Russia or the South African diamond fields. The spatialization of risk is maintained to the end.

A Study in Scarlet (1897) had maintained that Victorian distinction between a risky, savage elsewhere and a safe, civilised home. Crimes incubated in the Wild West are detected and punished once their repercussions arrive at the door of 221B, Baker Street. Yet both the criminal and the two murdered men are foreigners, whose crimes disturb the peace but claim 
no British victims, and the narrative slackens when it is drawn away from Holmes and Watson and into the reminiscences of the perpetrator's overseas adventures. Doyle seems to have recognised this weakness in the novel: its sequel, The Sign of the Four (1890), retains the structural division between a civilised metropolis (London) and a wild colonial hinterland (India), but confines the foreign portion of the narrative to the villain's confession in the final chapter. This is much more in line with Doyle's practice in the stories he began to write a short time later, beginning with "A Scandal in Bohemia” (1891), which despite its thrillingly international title contains only the briefest of references to events in central Europe. Only one of the dozen stories in The Adventures of Sherlock Holmes - "The Boscombe Valley Mystery”, in which ill doings in Australia lead to violent ends in Herefordshire - really indulges in the spatialization of risk, while the other adventures all concern misdeeds perpetrated in England itself. The sharp narrative distinction between risky hinterland and safe metropolis no longer holds sway.

The most successful of all the Holmes stories, The Hound of the Baskervilles (1902), sets up a geographical binary within England itself, in the distance between London and Dartmoor, and in doing so finally unsettles the moral geography of risk that structures colonial adventure narratives like those of Rider Haggard. It is not that The Hound of the Baskervilles is oblivious to modernity's risky international entanglements - its plot, after all, depends upon Sir Henry Baskerville's profits in South African speculation and the arrival of an American heir - but rather that it renounces the fundamental narrative division between an uncertain elsewhere and a safe, predictable home. Like the best of the short Holmes adventures, in which Doyle had a narrower canvas and less room to digress, it demonstrates a more sophisticated understanding of the hidden connections - political, familial, financial - which were beginning to unite those seemingly disparate spaces in a single global system. Only the final Holmes novel, The Valley of Fear (1915), attempts to revive the narrative separation between foreign crimes and domestic 
disruption. By that time, world events had contrived to make the distinction seem more anachronistic than ever.

My main claim in this essay has been that the problematic treatment of chance in the Sherlock Holmes stories does not really amount to an inconsistency within the stories themselves, but rather reflects real contradictions within the public re-evaluation of chance and risk that took place during the years of their composition. Doyle's stories, as I read them, are swept along in a new current of late-Victorian and Edwardian thinking about chance not simply as a threat to stability and order but also as a field of opportunity for moral and material improvement. This new kind of thinking emerged across a wide range of intellectual and social domains. Ian Hacking has written at length about the nineteenth century's "taming of chance": the set of steps in mathematics, physics, philosophy, and social science by which it became possible by the end of the century to take chance seriously. The deterministic world-view of the Enlightenment, which had inferred the hidden workings of an unknown agency behind the appearance of chance events, was replaced by a modern conception of probability, in which non-deterministic "laws" of chance came to be observable as distributions within numerical data-sets. Among other key developments, the creation of sophisticated statistical models by governments and institutions made it possible to understand chance as a kind of system in its own right. "Chance became tamed, in the sense that it became the very stuff of the fundamental processes of nature and of society" ${ }^{15}$ Holmes's continual emphasis on probability - "I could only say what was the balance of probability" - is of a piece with this new mode of thought (p. 93).

From the middle of the nineteenth century onward, however, chance was being tamed in other senses as well. Efforts were being made, legislatively and imaginatively, to untangle the necessary speculative activity conducted in financial markets from its associations with gambling 
in the literature and social commentary of Victorian moralists. Meanwhile, the geographical apportioning of risk between the the secure spaces of the British homeland and the risky spaces of the imperial margin was beginning to give way to a new view of risk as a ubiquitous feature of modern society. By the century's end, these two problems - of economic and spatialized risk - had been drawn together by an increasing public awareness of complex imperial and international economic relations which meant that chance events in distant lands might effect sudden and severe alterations in the fortunes of British subjects.

In their willingness to give chance its due while insisting that not everything can or should be left to a roll of the dice, Doyle's Sherlock Holmes stories are uncommonly well-attuned to these changes. They speak of a new world of global finance capital governed not by regular patterns of production and consumption but by unpredictable and unknowable processes which appear all but indistinguishable from the laws of chance. Such laws, moreover, were always in danger of being subverted by those cunning and unscrupulousness enough to cheat their way out of the risk which had come to be understood as the price of reward, or by those who failed to accept the consequences when their risk-taking resulted in ruin. Risk had to be made to conform to the moral law, if only in the imaginary world of the adventure story. Holmes's struggle to tame chance, his capacity to weigh the odds, and his ability to infer the relationship between seemingly random local phenomena and unpredictable systems of remarkable scale and complexity, made him the ideal hero for a society in desperate need of reassurance that the modern world was worth the risk.

\footnotetext{
'Arthur Conan Doyle, The Firm of Girdlestone (London: Chatto \& Windus, 1890), p. 28.

${ }^{2}$ Ronald Knox, "Studies in the Literature of Sherlock Holmes", in Essays in Satire (New York: E.P. Dutton, 1930), 145-175 (p. 170).
} 
${ }^{3}$ All references within the Sherlock Holmes novels and stories are to The Penguin Complete Sherlock Holmes (Harmondsworth: Penguin, 1985).

"Christopher Clausen, "Sherlock Holmes, Order, and the Late-Victorian Mind”, The Georgia Review 38:1 (Spring 1984), 104-123 (p. 109).

${ }^{5}$ Roger Munting, An Economic and Social History of Gambling (Manchester: Manchester University Press, 1996), p. 29.

${ }^{6}$ Charles Dickens, Nicholas Nickleby, ed. Paul Schlicke (Oxford: Oxford University Press, 1998), p. 5.

${ }^{7}$ See David C. Itzkowitz, "Fair Enterprise or Extravagant Speculation: Investment, Speculation, and Gambling in Victorian England”, Victorian Studies 45:1 (Autumn, 2002), 121-147.

${ }^{8}$ Arthur Conan Doyle: A Life in Letters, ed. Jon Lellenberg, Daniel Stashower, and Charles Foley (London: HarperCollins, 2007), p. 247.

${ }^{9}$ Ibid., pp. 460-61.

${ }^{10}$ Arthur Conan Doyle, Memories and Adventures (Cambridge: Cambridge University Press, 2012), p. 240 .

${ }^{1 "}$ Elaine Freedgood, Victorian Writing about Risk (Cambridge: Cambridge University Press, 2004), p. 1.

${ }^{12}$ Francis O'Gorman, "Speculative Fictions and the Fortunes of H. Rider Haggard”, in Francis

O'Gorman (ed.), Victorian Literature and Finance (Oxford: Oxford University Press, 2007), 157-172.

${ }^{13}$ Ibid., p. 165.

${ }^{14}$ The Firm of Girdlestone, p. 202.

${ }^{15}$ Ian Hacking, The Taming of Chance (Cambridge: Cambridge University Press, 1990), p. vii. 